\title{
My personal tribute to Dr. Mary Ellen Avery
}

\section{llene R. S. Sosenko*}

Division of Neonatology, Department of Pediatrics, University of Miami Miller School of Medicine, Miami, FL, USA

${ }^{*}$ Correspondence: isosenko@miami.edu

\section{Edited and reviewed by:}

John Steven Torday, University of California Los Angeles, USA

Keywords: neonatology, research, IDM, mentor, Mary Ellen Avery

Because my husband was planning to pursue a fellowship in adolescent medicine at Boston Children's Hospital, I was set to interview there in July of 1974 for a third year of pediatric training. I was just starting my second year of pediatrics in Los Angeles and had been focusing more on the mechanics of completing pediatric training than on choosing a fellowship. Dr. Mary Ellen Avery had just become Children's Physician-in-Chief. In fact, she was still finding her way about the place, both physically and professionally. It was my second interview, the first resulting in less than positive news about the possibility of my obtaining a senior pediatric residency for the coming year. She did not let me be discouraged, made it known that she would welcome me there, and suggested I could pursue the start of a fellowship before completing my full pediatric training. What type of fellowship? I certainly hadn't spent much time contemplating this. How about neonatology, she suggested, and immediately arranged for me to see Dr. Bill Taeusch, newly appointed Neonatology Division Director. So serendipity, and more importantly, Dr. Mel Avery are responsible for my career in neonatology: I joined the first official JPN fellows' group that started training in July of 1975.

Dr. Avery was a pioneering researcher in the field of neonatology and a great research motivator as well. She had overseen a recent publication associating an increased risk of hyaline membrane disease in infants of diabetic mothers (1). She "shepherded" me into examining this further, thus leading me both to the delivery room to collect infants' cord blood for C-peptide measurements (2) and into the animal lab with alloxan-diabetic pregnant rabbits and the lung development of their offspring (3-7). I remember her delight when I presented my findings at research meetings and had my first peerreviewed publications in the New England Journal of Medicine (2) and Journal of Applied Physiology (3). In fact, when I moved on to University of Miami, I continued the line of research looking at lung development in the animal model of the IDM, this time examining pulmonary antioxidant enzyme development in offspring of streptozotocin-treated rats (8).

She opened her heart to me not just professionally but socially and personally as well. I remember a cozy Thanksgiving evening when just she, my husband, and I sat by the fire in her Wellesley condo and dined on delicious leftovers from the day. She hosted the two of us to a very special Boston evening: a "double date" with Dr. Fred Rosen for dinner at the Harvard Club and then to hear the Boston Symphony. When I was about to have my first child, she was glowing when I came to her with the news. She wanted to make sure I would be nursing him which of course I was. When he was born, she presented us with a beautifully framed print of a mother rabbit and her pups (how appropriate!) which we hung above his changing table. And once I had successfully established nursing and returned to work, she invited me to write an article with her on the benefits of breast feeding for the Harvard Medical School Health Letter (9).

My respect and admiration for Dr. Mary Ellen Avery are without bounds. There is no doubt that Mel brought me into neonatology, fostered my career, and opened her intellect and heart to me many years ago. For this I am eternally grateful.

\section{REFERENCES}

1. Robert MF, Neff RK, Hubbell JP, Taeusch HW, Avery ME. Association between maternal diabetes mellitus and respiratory distress syndrome in the newborn. N Engl J Med (1976) 294:357-60. doi:10. 1056/NEJM197602122940702

2. Sosenko IR, Kitzmiller JL, Loo SW, Blix P, Rubenstein AH, Gabbay KH. The infant of the diabetic mother: correlation of increased cord C-peptide levels with macrosomia and hypoglycemia. $N$ Engl J Med (1979) 301:859-862.

3. Sosenko IR, Lawson EE, Demottaz V, Frantz ID. Functional delay of lung maturation in fetuses of alloxan diabetic rabbits. J Appl Physiol (1980) 48:643-647.

4. Sosenko IR, Hartig-Beecken I, Frantz ID. Cortisol reversal of functional delay of lung maturation in fetuses of diabetic rabbits. J Appl Physiol (1980) 49:971-974.

5. Sosenko IR, Frantz ID, Roberts RJ, Meyrick B. Morphologic disturbance of lung maturation in fetuses of alloxan diabetic rabbits. Am Rev Respir Dis (1980) 122:687-696.

6. Frantz ID III, Sosenko IR. Lung maturation in an experimental model of diabetes in pregnancy. J Jpn Med Soc Biol Interface (1980) 11:76-81.

7. Sosenko IR, Werthammer J, Cunningham MD, Frantz ID III. Surfactant in diabetic offspring not affected by inhibitors or lecithin fatty acids. J Appl Physiol (1983) 54:1097-1100.

8. Sosenko IRS, Frank L. Lung development in the streptozotocin rat fetus: antioxidant enzymes and survival in high oxygen. Pediatr Res (1986) 20:67-70

9. Avery ME, Sosenko IR. Breast feeding. Harv Med Sch Health Lett (1979) 4:3-4.

Received: 07 March 2014; accepted: 10 March 2014; published online: 24 March 2014.

Citation: Sosenko IRS (2014) My personal tribute to Dr. Mary Ellen Avery. Front. Pediatr. 2:23. doi: 10.3389/fped.2014.00023

This article was submitted to Neonatology, a section of the journal Frontiers in Pediatrics.

Copyright (C) 2014 Sosenko. This is an open-access article distributed under the terms of the Creative Commons Attribution License (CC BY). The use, distribution or reproduction in other forums is permitted, provided the original author(s) or licensor are credited and that the original publication in this journal is cited, in accordance with accepted academic practice. No use, distribution or reproduction is permitted which does not comply with these terms. 